\title{
MODEL PENDIDIKAN PESANTREN: STUDI KASUS DI PESANTREN RAKYAT AL-AMIN SUMBERPUCUNG KAB. MALANG
}

\author{
I'anatut Thoifah \\ Universitas Muhammadiyah Malang, Indonesia \\ E-mail: iana.atthoif17@gmail.com
}

\begin{abstract}
Abstrak
Sistem adalah sekumpulan unsur pendidikan yang saling terkait dan berhubungan serta saling mempengaruhi untuk mencapai suatu tujuan tertentu. Salah satu upaya yang dapat dilakukan adalah melalui pengembangan sistem pendidikan Islam. Sedangkan model merupakan produk dari sistem yang berkembang. Fokus penelitian ini adalah bagaimana penerapan model pondok pesantren "Rakyat Al-Amin" di Sumberpucung Malang yang meliputi beberapa komponen dari pondok pesantren itu sendiri: pesantren, masjid, buku klasik Islam, santri dan kiyai. Hasil penelitian menunjukkan adanya perbedaan komponen pondok pesantren secara umum dan komponen pondok pesantren rakyat. Pada kenyataannya pondok pesantren rakyat hanya memiliki tiga komponen yaitu pengajaran buku klasik islami, santri dan kyai, namun bukan berarti komponen pesantren lainnya tidak penting, komponen lainnya hanya memiliki fungsi yang berbeda.
\end{abstract}

Kata Kunci: Komponen Pendidikan, Model, Pesantren, Pendidikan Islam, Kyai

\begin{abstract}
System is a set of elements of education which are related and connected each other and give influence each other to achieve a certain goal. One of attempt that can be done is through developing system of Islamic Education there, while the model is a product of developing system. Focus of this research is how implementation of the model "Rakyat Al-Amin" Islamic boarding school in Sumberpucung, Malang including some components of Islamic boarding school itself: boarding, mosque, Islamic classic books, students and kiyai. The result of this research shows the difference of the components of Islamic boarding school commonly and the components of Rakyat Islamic boarding school. In the reality Rakyat Islamic boarding school only has 3 components such as teaching Islamic classic book, students and kyai, but it doesn't mean that the other components of Islamic boarding school are not important, the other components just have different function.
\end{abstract}

Keyword: Education Componen, Model, Islamic Boarding School, Kyai 


\section{Pendahuluan}

Selama ini penerapan pendidikan Islam, baik yang formal maupun non-formal seperti halnya yang terjadi di pesantren dirasa menakutkan. Hal ini karena dilatarbelakangi oleh beberapa faktor, yaitu sejumlah peraturan yang berlaku di dalamnya serta pembiayaan pendidikan yang rumit dan tinggi untuk kalangan ekonomi dan pendidikan menengah ke bawah. Alhasil, potensi peserta didik, baik potensi yang beraras pada pencapaian individu untuk menjadi seorang ahli agama atau seorang pakar di bidang tertentu, mereka yang berasal dari masyarakat akar rumput menjadi tidak tersentuh. Padahal, sangat mungkin banyak potensi mereka yang merupakan "mutiara, emas, dan permata", yang sayangnya terpendam karena ekonomi kelaurga yang mengalami keterbatasan.

Sebab itu, fenomena perkembangan abad mutakhir menghendaki adanya model pendidikan yang komprehensif. Dewasa ini, masyarakat menghendaki adanya pembinaan peserta didik yang dilaksanakan secara seimbang antara nilai dan sikap, pegetahuan, kecerdasan dan keterampilan, serta kemampuan komunikasi dan kesadaran akan ekologi lingkungan.

Model pendidikan yang demikian itu, menjadi syarat penting yang perlu dibudayakan agar peserta didik benar-benar siap menghadapi tantangan zaman di masa depan. Berbagai keterampilan tersebut sangat berguna untuk mencari pekerjaan di dunia usaha yang semakin kompetitif. Hal tersebut sebagai sebuah upaya dalam menyesuaikan diri secara konstruktif terhadap perubahan-perubahan yang terjadi di era kontemporer.

Pendidikan berbasis masyarakat sebagai wahana dan sarana strategis sebagai perwujudan demokratisasi pendidikan senantiasa menghendaki adanya keterlibatan, dukungan, dan kepemilikan masyarakat dalam bidang pendidikan, yang terbebas dari intervensi pemerintah. Slogan "bebaskan pendidikan dari belenggu kekuasaan"1 dan "kembalikan pendidikan kepada masyarakat" 2 merupakan inti wacana pendidikan berbasis masyarakat. Dengan slogan ini, dapat dilihat secara sepintas bahwa pendidikan berbasis masyarakat merupakan konsep yang perlu mendapat perhatian serius dari pemerintah.

\section{Sistem dan Pesantren}

Istilah sistem berasal dari bahasa Yunani System yang berarti hubungan fungsional yang teratur antara unit-unit atau komponen-komponen. ${ }^{3}$ Ada pula yang mengemukakan tentang pengertian sistem sebagai suatu keseluruhan yang tersusun dari sekian bagian; hubungan yang berlangsung di antara satuan-satuan atau komponen secara teratur. Sistem adalah jumlah keseluruhan dari bagian-bagian yang bekerja secara sendiri-sendiri dan bersama untuk mencapai hasil yang diperlukan, berdasarkan keperluan. Jadi, dengan kata lain istilah "system" itu mengandung arti komponen yang saling berhubungan secara teratur dan

\footnotetext{
${ }^{1}$ Hadi Supeno, Pendidikan dalam Belenggu Kekuasaan, (Magelang: Pustaka Paramedia, 1999).

${ }^{2}$ Winarno Surakhmad, Kembalikan pendidikan Pada Masyarakat, dalam http://www.kompas.com/kompas\%2D- cetak/0111/20/dikbud/kemb09.html, berita ini dimuat dalam harian Kompas tanggal 20 November 2001. (Diakses pada tanggal 10 April 2013).

3 Tohari Musnamar, Bimbingan dan Wawanwuruk sebagai Suatu Sistem, (Yogyakarta: Cendikia Sarana Informatika, 1985), hlm. 38
} 
merupakan satu keseluruhan yang bekerja secara sendiri-sendiri maupun bersama untuk mencapai satu tujuan.

Rumusan lain menyatakan, sistem adalah kumpulan berbagai komponen yang berinteraksi satu dengan lainnya membentuk suatu kesatuan dengan tujuan yang jelas. ${ }^{4}$ Dengan demikian, sistem merupakan himpunan komponen-komponen atau bagian yang saling berkaitan yang bersama-sama berfungsi untuk mencapai suatu tujuan.

Untuk mengetahui suatu sistem atau bukan, antara lain dapat dilihat dari ciri- cirinya. Ada beberapa rumusan mengenai ciri-ciri sistem ini yang pada dasarnya satu sama lain melengkapi. Pada umumnya ciri-ciri sistem itu adalah: bertujuan, punya batas, terbuka, tersusun dari sub sistem, ada saling keterkaitan dan saling tergantung, merupakan satu kebulatan yang utuh, melakukan kegiatan transformasi, ada mekanisme kontrol, dan memiliki kemampuan mengatur dan menyesuaikan diri sendiri. ${ }^{5}$

Satu sistem bisa mempunyai tujuan lebih dari satu macam tujuan. Secara umum tujuan sistem adalah menciptakan sesuatu yang berharga dan mempunyai nilai, entah apa wujud dan ukurannya. Penciptaan atau pencapaian sesuatu yang bernilai itu dilakukan dengan memadukan dan mendayagunakan berbagai macam bahan atau dengan suatu cara tertentu. Misalnya, sekolah yang terdiri dari: orang, kurikulum, sarana dan prasarana. Tujuan khusus sistem tersebut antara lain: a). Manusia dapat terdidik; b). pengembangan ilmu; dan c). Pembinaan masyarakat. ${ }^{6}$

Sistem keterbukaan dibedakan dua macam, antara lain:7a). Sistem terbuka adalah sistem yang berhubungan dengan lingkungannya, komponen-komponennya dibiarkan mengadakan hubungan keluar dari "batas luar" sistem; dan b). Sistem tertutup adalah sistem yang terisolasikan dari segala pengaruh luar sistem itu sendiri, dari pengaruh sistem yang lebih besar atau lebih luas atau dari lingkunganya.

Salah satu konsep kunci untuk melihat sistem adalah konsep kebulatan keseluruhan yang mengandung makna atau sifat "wholism". Maksud yang terkandung di dalam konsep ini adalah, bahwa sistem sebagai satu kesatuan yang bulat bukanlah sekedar kumpulan dari bagian-bagiannya. Salah satu prinsip dari sistem pendidikan Islam adalah menggunakan metode pendekatan holistik (menyeluruh) terhadap manusia yang meliputi dimensi jasmani dan rohani, dan sesuai dengan fitrahnya yang meliputi semua aspek kemanusiaan dan kehidupan, baik yang dapat dijangkau oleh akal maupun yang hanya dapat diimani oleh hati.

\footnotetext{
4 Fuad Amsyari, Keharmonisan Lingkungan sebagai Determinan Keberhasilan Pembangunan Pendidikan: Suatu Analisis dari Pandangan Islam, (Surabaya: Indah Offset, 1986), hlm. 52.

${ }^{5}$ Ridlwan Nasir, Mencari Tipologi Format Pendidikan Ideal, (Yogyakarta: Pustaka Pelajar, 2005), hlm. 28.

${ }^{6}$ Ridlwan Nasir, Mencari Tipologi Format Pendidikan Ideal.....hlm. 28-29

7 Ridlwan Nasir, Mencari Tipologi Format Pendidikan Ideal.....hlm. 29. Lihat juga Rusadi Kantaprawira, Aplikasi Pendekatan Sistem dalam Ilmu-ilmu Sosial, (Jakarta: Bunda Karya, 1987), hlm. 21.
} 
Semuanya dikembangkan secara menyeluruh dan seimbang, bukan hanya akalnya saja tetapi juga hatinya, bukan hanya lahiriah-nya saja tetapi juga batiniah-nya. ${ }^{8}$

Sementara itu, kata pesantren berasal dari kata santri, ${ }^{9}$ dengan awalan pe dan akhiran an berarti tempat tinggal para santri. ${ }^{10}$ Di Indonesia istilah pesantren lebih populer dengan sebutan pondok pesantren. Lain halnya dengan pesantren, pondok berasal dari bahasa Arab funduq yang berarti hotel, asrama, rumah, dan tempat tinggal sederhana. ${ }^{11}$

Paparan tersebut memberikan keterangan bahwa pondok pesantren merupakan lembaga pendidikan Islam yang memberikan pendidikan dan pengajaran serta mengembangkan dan menyebarkan ilmu agama Islam, sedangkan orang yang belajar di pesantren disebut dengan santri, baik yang bertempat tinggal di dalam pesantren meski ada juga yang pulang pergi dari rumahnya masing-masing.

Secara fisik, sebuah pesantren biasanya terdiri dari unsur-unsur berikut: dipusatkan ada sebuah masjid atau langgar, surau yang dikelilingi bangunan tempat tinggal kiai (dengan serambi tamu, ruang depan, kamar tamu), asrama untuk pelajar (santri) serta ruangan-ruangan belajar. ${ }^{12}$ Pesantren sering berada di perbatasan pedesaan yang terpisah, dibatasi dengan pagar. Mereka kebanyakan menguasai lahan pertanian sendiri, yang sering dihibahkan oleh penduduk desa untuk tujuan-tujuan (wakaf). ${ }^{13}$

Dalam teori lain dijelaskan, bahwa pesantren memiliki karakteristik yang khusus. Adapun secara umum, dapat dikatakan bahwa karakteristik pesantren terletak pada komponenkomponen yang ada di dalamnya. Komponen-komponen yang dimaksud meliputi: pondok,

${ }^{8}$ Muhammad Qutub, Sistem Pendidikan Islam, Peterj.: Salman Harun, (Bandung: al-Ma'arif, 1984), hlm. 27.

9 Dalam penelitiannya, Clifford Geertz berpendapat, kata santri mempunyai arti luas dan sempit. Dalam arti sempit santri adalah seorang murid satu sekolah agama yang disebut pondok atau pesantren. oleh sebab itulah perkataan pesantren diambil dari perkataan santri yang berarti tempat untuk para santri. Dalam arti luas dan umum santri adalah bagian penduduk jawa yang memeluk Islam dengan benar-benar, bersembahyang, pergi ke masjid dan berbagai aktifitas lainnya. Lihat Clifford Geertz, Abangan Santri, Priyayi dalam Masyarakat Jawa, Peterj.: Aswab Mahasin, (Jakarta: Dunia Pustaka Jaya, 1983), hlm. 268; Abdul Munir Mulkhan, Runtuhnya Mitos Politik Santri: Strategi Kebudayaan dalam Islam, (Yogyakarta: Sipress, 1994), hlm, 1.

10 Zamakhsyari Dhofier, Tradisi Pesantren: Studi tentang Pandangan Hidup Kiai (Jakarta: LP3ES, 1994), hlm. 18; Tim Penyusun, Kamus Besar Bahasa Indonesia, (Jakarta: Balai Pustaka, 1989, hlm. 677; Saliman \& Sudarsono, Kamus Pendidikan: Pengajaran dan Umum, (Jakarta: Rineka Cipta, 1994), hlm. 180; Tim Penyusun, Ensklopedi Islam Indonesia, (Jakarta: Djambatan, 1992), hlm. 771.

11 Hasbullah, Sejarah Pendidikan Islam di Indonesia: Lintasan Sejarah Pertumbuhan dan Perkembangan, (Jakarta: Rajawali Pers, 1996), hlm. 138.

${ }_{12}$ Manfred Ziemek, Pesantren dalam Perubahan Sosial, (Jakarta: P3M, 1986), hlm. 101.

${ }^{13}$ Manfred Ziemek, Pesantren dalam Perubahan Sosial, (Jakarta: P3M, 1986), hlm. 101. 
masjid, santri, pengajaran kitab-kitab Islam klasik, dan kiai. Kelima komponen pesantren akan diuraikan secara singkat berikut ini: ${ }^{14}$

\section{Skema 1: Empat Komponen Pesantren Menurut Manfred}

Skema 2: Lima Komponen

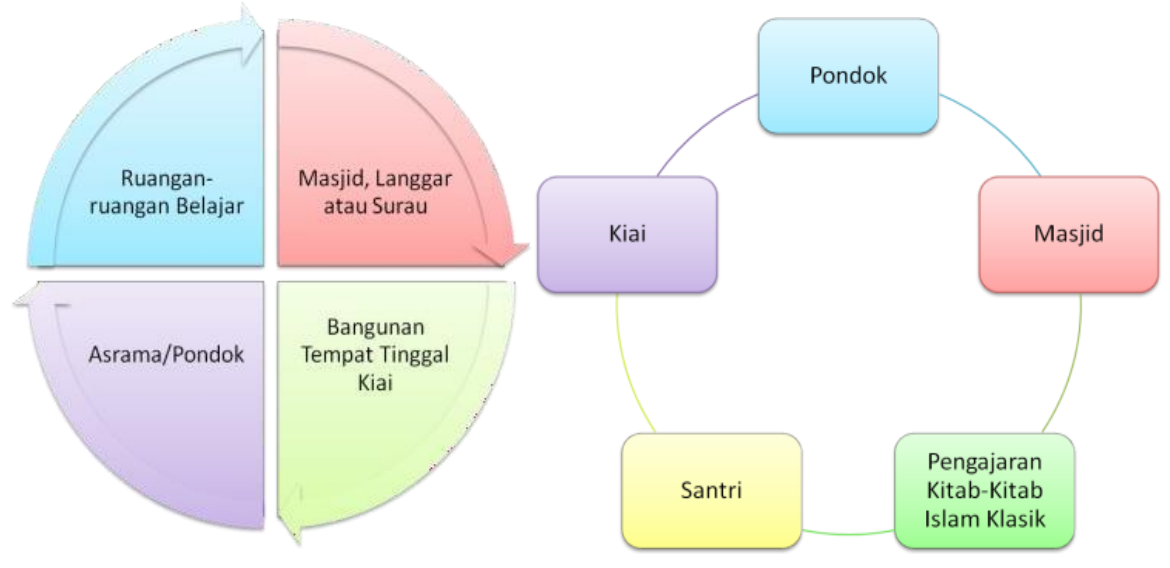

Dalam dinamikanya di masyarakat, pesantren mengalami perkembangan yang luar biasa. Pembagian pesantren beserta tipologinya sebagai berikut:15 Pertama, Pesantren salafi. Jenis pesantren salafi ini merupakan jenis pesantren yang tetap mempertahankan pengajaran kitabkitab Islam klasik sebagai inti pendidikannya; Kedua, Pesantren khalafi. Pesantren jenis ini tampaknya menerima hal-hal baru yang dinilai baik di samping tetap mempertahankan tradisi lama yang baik. Pesantren sejenis ini mengajarkan pelajaran umum di madrasah dengan sistem klasikal dan membuka sekolah-sekolah umum di lingkungan pesantren; Ketiga, Pesantren kilat. Pesantren ini merupakan pesantren yang berbentuk semacam training dalam waktu relatif singkat dan biasa dilaksanakan pada waktu libur sekolah atau pada bulan ramadhan. Pesantren ini menitikberatkan pada keterampilan ibadah dan kepemimpinan. Sedangkan santri terdiri dari pelajar sekolah non pesantren yang dipandang perlu mengikuti kegiatan keagamaan di pesantren atau di sekolah-sekolah.

Pesantren dengan corak dan nama-nama tertentu dewasa ini telah mengalami berbagai perkembangan. Di mana ada beberapa nama yang turut melekat pada pesantren, antara lain: pesantren terintegrasi, pesantren metal, pesantren alam, pesantren buruh pabrik, atau bahkan ada pesantren rakyat.

${ }^{14}$ Abdullah Aly, Pendidikan Islam Multikultural di Pesantren, (Yogyakarta: Pustaka Pelajar, 2011), hlm. 159.

${ }^{15}$ M. Jacub, Pondok Pesantren dan Pengembangan Masyarakat Desa, (Bandung: Angkasa, 1981), hlm. 25; lihat juga dalam CH. Mufidah, Pesantren Rakyat, dalam jurnal el-Harakah Vol. 14, No. 1 Tahun 2012, hlm. 126. 
Jika pesantren ini dilihat dari aspek kurikulum juga mempunyai sisi yang menarik. Di mana istilah kurikulum tidak ditemukan dalam kamus besar sebagian pesantren, terutama pada masa sebelum perang. Walaupun materinya ada di dalam praktek pengajaran, bimbingan rohani dan latihan kecakapan dalam kehidupan sehari- hari di pesantren, yang merupakan kesatuan dalam proses pendidikan di pesantren. Ini disebabkan karena memang pondok pesantren lama mempunyai kebiasaan untuk tidak merumuskan dasar dan tujuan pendidikannya secara eksplisit, ataupun meruncingkan secara tajam dalam bentuk kurikulum dengan rencana pelajarannya dan masa belajarnya.

Kurikulum pesantren sebenarnya meliputi seluruh kegiatan yang dilakukan di pesantren selama sehari semalam (yang saat itu belum dirumuskan). Di luar pelajaran banyak kegiatan yang benilai pendidikan dilakukan di pondok berupa latihan hidup sederhana, mengatur kepentingan bersama, mengurusi kebutuhan sendiri, latihan bela diri, ibadah dengan tertib dan riyadlah. ${ }^{16}$

Ada beberapa pesantren yang mencoba mencari jalan sendiri yang diharapkan akan menghasilkan lebih banyak dalam waktu yang lebih singkat. Pesantren semacam ini menyusun kurikulumnya berdasarkan pemikiran akan kebutuhan anak didik dan masyarakat. Sedangkan metode pengajaran yang lazim disebut sebagai weton dan sorogan. ${ }^{17}$

Era globalisasi dan modernisasi seperti ini Metode weton dan sorogan mulai ditinggalkan atau didampingi dengan sistem madras atau klasikal dengan mempergunakan alat peraga, evaluasi dengan berbagai variasinya dan juga latihan- latihan. Prinsip-prinsip psikologi perkembangan dalam pendidikan dan proses belajar mulai diterapkan, dan metode pengajaran baru pada masing-masing fakultas dipraktekkan. Kenaikan tingkat, pembagian kelas dan pembahasan masa belajar diadakan, sembari administrasi sekolah-pun dilaksanakan dalam organisasi yang tertib. Setelah adanya penelaahan terhadap dunia pendidikan Islam tradisional dan mempelajari pikiran-pikiran serta gagasan-gagasannya, nampaknya Nurcholish Madjid berobsesi menciptakan suatu sistem pendidikan yang memiliki keterpaduan antara unsur keIslaman, keIndonesiaan, dan keilmuan. Sistem pendidikan terpadu ini diproyeksikan sebagai suatu alternatif untuk menuju masyarakat madani. ${ }^{18}$

\footnotetext{
${ }^{16}$ Abdurrahman Wahid, dkk., Pesantren dan Pembaharuan, (Jakarta: LP3ES, 1988), hlm. 86-87.

${ }_{17}$ Abdurrahman Wahid, dkk., Pesantren dan Pembaharuan, (Jakarta: LP3ES, 1988), hlm. 89-90.

18 Yasmadi, Modernisasi Pesantren: KritikNurcholish Madjid Terhadap Pendidikan Islam Tradisional, (Jakarta: Ciputat Press, 2002), hlm. 121.
} 


\section{Daftar Pustaka}

Supeno, Hadi Supeno. Pendidikan dalam Belenggu Kekuasaan. Magelang: Pustaka Paramedia, 1999.

Surakhmad, Winarno. Kembalikan Pendidikan Pada Masyarakat, dalam http://www.kompas.com/kompas\%2D- cetak/0111/20/dikbud/kemb09.html, berita ini dimuat dalam harian Kompas (20 November 2001). Diakses pada 10 April 2013.

Musnamar, Tohari. Bimbingan dan Wawanwuruk sebagai Suatu Sistem. Yogyakarta: Cendikia Sarana Informatika, 1985.

Amsyari, Fuad. Keharmonisan Lingkungan sebagai Determinan Keberhasilan Pembangunan Pendidikan: Suatu Analisis dari Pandangan Islam. Surabaya: Indah Offset, 1986.

Nasir, Ridlwan. Mencari Tipologi Format Pendidikan Ideal. Yogyakarta: Pustaka Pelajar, 2005.

Kantaprawira, Rusadi. Aplikasi Pendekatan Sistem dalam Ilmu-ilmu Sosial. Jakarta: Bunda Karya, 1987.

Qutub, Muhammad. Sistem Pendidikan Islam, Peterj.: Salman Harun. Bandung: al-Ma'arif, 1984.

Clifford, Geertz. Abangan Santri, Priyayi dalam Masyarakat Jawa, Peterj.: Aswab Mahasin. Jakarta: Dunia Pustaka Jaya, 1983.

Munir Mulkhan, Abdul. Runtuhnya Mitos Politik Santri: Strategi Kebudayaan dalam Islam. Yogyakarta: Sipress, 1994.

Dhofier, Zamakhsyari. Tradisi Pesantren: Studi tentang Pandangan Hidup Kiai. Jakarta: LP3ES, 1994.

Tim Penyusun, Kamus Besar Bahasa Indonesia. Jakarta: Balai Pustaka, 1989.

Saliman \& Sudarsono, Kamus Pendidikan: Pengajaran dan Umum. Jakarta: Rineka Cipta, 1994.

Tim Penyusun, Ensklopedi Islam Indonesia. Jakarta: Djambatan, 1992.

Hasbullah, Sejarah Pendidikan Islam di Indonesia: Lintasan Sejarah Pertumbuhan dan Perkembangan. Jakarta: Rajawali Pers, 1996.

Ziemek, Manfred. Pesantren dalam Perubahan Sosial. Jakarta: P3M, 1986.

Aly, Abdullah. Pendidikan Islam Multikultural di Pesantren. Yogyakarta: Pustaka Pelajar, 2011. Jacub, M. Pondok Pesantren dan Pengembangan Masyarakat Desa. Bandung: Angkasa, 1981.

CH. Mufidah, Pesantren Rakyat, dalam jurnal el-Harakah Vol. 14, No. 1 Tahun 2012.

Wahid, Abdurrahman, dkk., Pesantren dan Pembaharuan. Jakarta: LP3ES, 1988.

Yasmadi, Modernisasi Pesantren: Kritik Nurcholish Madjid Terhadap Pendidikan Islam Tradisional. Jakarta:Ciputat Press, 2002. 